\title{
Ewa Wszendybyl-Skulska
}

Jagiellonian University in Krakow

e-mail: e.wszendybyl-skulska@uj.edu.pl

ORCID: 0000-0003-1308-6803

\section{MOTIVATING HOTEL EMPLOYEES IN POLAND}

\section{MOTYWOWANIE PRACOWNIKÓW HOTELI W POLSCE}

DOI: $10.15611 / \mathrm{pn} .2019 .10 .17$

JEL Classification: J81, L83, M12

\begin{abstract}
Summary: Research into the effective ways of motivating employees occupies an important place in the literature of the subject. For many years the research on motivation to work has mainly been focused on the payment. Nowadays, more and more attention is given to using the non-financial tools in the motivation process. Today, motivating employees to work in the hotel industry includes a number of personalized incentive instruments. The purpose of the study is to check what types of motivators are most often used by hotel managers in Poland to motivate line employees. The research has shown that hoteliers in Poland most often use such motivators as work atmosphere, interpersonal relations, showing respect, rewards and bonuses, salary, and flexible working hours, while the least used are those based on digital solutions that can support the daily work of employees, communication with colleagues and superiors and their development.
\end{abstract}

Keywords: hotels, motivating, technologies, work.

Streszczenie: Ważne miejsce w literaturze przedmiotu zajmują analizy dotyczące skutecznych sposobów motywowania pracowników. Przez wiele lat badania nad motywacją do pracy dotyczyły głównie płac. Współcześnie coraz większą uwagę skupia się na wykorzystywaniu w procesie motywacji narzędzi pozafinansowych. Motywowanie pracowników do pracy w hotelu obejmuje obecnie wiele spersonalizowanych instrumentów motywacyjnych. Celem niniejszego opracowania jest sprawdzenie, jakiego rodzaju motywatory są najczęściej wykorzystywane przez zarządzających hotelami w Polsce w motywowaniu pracowników liniowych. Badania wykazały, że hotelarze w Polsce najczęściej stosują takie motywatory, jak atmosfera pracy, relacje interpersonalne, okazywanie szacunku i uznania, nagrody i premie, wynagrodzenie, elastyczny czas pracy. Najrzadziej stosowane są zaś rozwiązania cyfrowe mogące wspomóc codzienną pracę pracowników, komunikację ze współpracownikami i przełożonymi oraz ich rozwój.

Slowa kluczowe: hotel, motywowanie, praca, technologie. 


\section{Introduction}

A hotel is an enterprise offering its services to guests 24 hours a day, 7 days a week, 365 days a year. Guests always require the highest quality of services offered, and this is provided by employees. Therefore, employees are the basic capital for enterprises in the hotel industry (Karatepe and Uludag, 2007). They have a direct impact on guests' satisfaction (Çetin, 2013) due to the inability to isolate them from consumer processes and the fact that they are part of the customer experience. They create this experience and are responsible for its efficient delivery in a cost-effective way (Deloitte, 2017).

Employees, as unique individuals, are the foundation of a specific culture and organizational climate, distinguishing a given hotel from others. Therefore, it is important for hotel managers to care for their employees, their satisfaction, commitment and motivation to work. It is a difficult challenge, especially today when the situation on the labour market is very unfavorable for employers. The decrease in unemployment together with the simultaneous dynamic increase in hotel investments, makes it increasingly difficult for hoteliers to find and keep their employees. Additionally, what should also be mentioned is the problems that the hotel industry has been facing (unfortunately not very effectively) for years. They include those resulting from the features of work in the industry, such as inadequate remuneration (DiPietro and Condly, 2007; Pizam, 2015), low job security, seasonality (Lee-Ross, 2005), limited training opportunities and development (Karatepe, 2009). There are also problems associated with unusual and long working hours and overload (Rowley and Purcell, 2001; Karatepe, Beirami, Bouzari, and Safavi, 2014) and poor working conditions (Maroudas, Kyriakidou, and Vacharis, 2008), which can be mentally exhausting for employees and negatively affect their well-being. Unless employees feel fulfilled in their work, they do not meet the expected standards (Mhlanga, 2018). According to Gordon and Adler (2017), regular emotional involvement in work (suppressing and regulating emotions) due to constant contact with guests has a negative impact on people, causing depression and stress. These difficult conditions and the resulting low well-being lead to excessive employee turnover (Cheng and Brown, 1998; Deery and Shaw, 1999; Pizam, 2015), and this is highest in the hotel industry, especially in highly developed and developing economies.

According to the consultants of the Hospitality Administrators International, the turnover rate for hotel employees in the USA is $50 \%$ for linear positions. The cost of losing an experienced employee is a half to one and a half times higher than the yearly salary (Consultants of Hospitality Administrators International, 2012). In Poland, according to the e-hotelarstwo.com portal, the staff turnover in hotel facilities is on average $30-60 \%$ yearly (Szafrański and Piasta, 2009).

Hotels lose money due to excessive rotation as they have to invest in training of their new employees. Rotation is highly dependent upon several key factors 
motivating employees to commitment which hotel managers should consistently manage: organizational culture, communication, strategy, payments and benefits, flexible work schedules and career development systems. Improvement of work satisfaction in employees not only reduces turnover, but also, as previously mentioned, provides guests with better service. Therefore, success in the hotel industry depends on its employees and how effectively they are motivated to help hotels achieve their goals.

Hence, the purpose of this study is to check what types of motivators are most often used by hotel facility managers in motivating line employees.

\section{Types of motivators}

Analysis of the theoretical foundations of motivation proves that employee's engagement in the performance of activities depends, to varying degrees, on their needs arising from the internal personal circumstances and other external environmental factors, which in a given case is generated by the enterprise. Therefore, the management of the enterprise is responsible for providing appropriate mechanisms that are to select the tools that stimulate employees to perform their tasks effectively and efficiently. The variety of these tools is manifested in the multitude of their classifications, among others by the direction of impact (positive and negative), scope of impact (internal and external) or/and ways of impact (individual and team-worked). However, the most important decisions regarding the choice of motivation tools are made in terms of their form. The most common division in literature distinguishes tangible and intangible motivators, while the most specific one consists of three groups: payroll, tangible and intangible non-wage payments (Wszendybył-Skulska, 2013). Even though motivating by salary was for years considered to be the most effective, today it becomes important to provide employees with various opportunities to take full advantage of their skills and talents by creating systems of incentives based on the needs of each employee using various tools, taking into account not only financial motivators, but also non-financial ones. Systems of motivation should offer a wide range of solutions and be individually adjusted to the various needs of employees and organizations (Yeboah and Abdulai, 2016). The improper selection of tools may demotivate employees and reduce their engagement in work (Wziątek-Staśko, 2016, p. 40)

Today, motivating is no longer subordinated to the "stimulus = reaction" principle. Instead, motivating means creating such conditions so that the employees themselves want to do what is expected to be done - not out of fear and necessity but from pleasure, from the sense of belonging to the organization and identifying with its values. Therefore, tangible motivators must be supplemented with intangible ones, such as building business atmosphere and culture that make people work with satisfaction and a sense of joy of creation. Not only motivators of a technical character, such as comfort and working conditions, but also psychological ones, such 
as praise, good interpersonal relations and the possibility of self-realization are significant. Numerous research results presented in the literature on the subject of HR reports are all confirmation of this.

Kingir and Mesci (2010), when studying the factors influencing the motivation of hotel employees, identified a group of 17, which are divided into four groups, i.e. social, intangible stimuli, responsibility and being appreciated, and teamwork. "Responsibility and recognition" proved to be the greatest influence on employees followed by "intangible incentives" and "teamwork". Similar conclusions were reached by Wasike and Ndivo (2015) and Yeboah and Abdulai (2016). While examining the impact of motivating factors on the efficiency of hotel employees and their job satisfaction, they proved that the most important factors affecting employees' motivation are "Responsibility and being appreciated" followed by "intangible incentives" and "teamwork".

Deloite (2019) in the report on trends in HR points out that employees more often expect integrated, digital work experience based on teams, performance and empowerment. This is associated with younger generations entering the organizations for whom digital solutions are becoming everyday life, who expect access to information and mobile learning as well as multidimensional communication.

Motivating employees to achieve organizational goals successfully is one of the main management tasks. It plays an important role in the development of key corporate competences and is a factor leading to the achievement of competitive advantage (Wasike and Ndivo, 2015). Motivating employees has a key impact on the intensity and sustainability of efforts to achieve the company's goals. The stronger the motivation, the more energetic the employee's approach to their tasks is. As the results of numerous studies reveal, highly motivated employees show a higher level of organizational commitment (Pandey, Wright, and Moynihan, 2008), work harder, achieve much better results at work (Leisink and Steijn, 2009) and increase organizational efficiency (Ritz, 2009; Taylor, 2015). On the other hand, it was found that dissatisfied employees are prone to counterproductive work behaviour (Tang and Chiu, 2003), which is particularly evident in the hotel industry in high staff turnover rates. From the point of view of the hotel industry, demotivated employees are now considered the most important problem (Enz, 2001). Hence, paying attention to the effective motivation of employees is the basis for success of every hotel. It not only improves work efficiency, but also reduces the costs associated with employee training.

\section{Research methodology}

The purpose of this study is to check what types of motivators are most frequently used by hotel managers in motivating line employees.

The study was based on the opinions of hotel managers and HR managers, in Poland, i.e. people who manage human capital in hotels on a daily basis. The questionnaire addressed to managers was built on the basis of the list of motivators 
identified by Kingir and Mesci (2010) as well as information taken from global reports on modern trends in the area of HR, which allowed to identify 19 motivators. Managers' opinions were collected via LinkedIn, which is an international platform focused on business communication. It is used for establishing industry contacts, reaching out to specialists from various industries and sectors. In Poland it is visited by a million interested internet users monthly developing their professional career. Over $90 \%$ of Polish managers use LinkedIn (Polski LinkedIn w liczbach, 2019) to present themselves, build networks and search for both information and people (Korzynski, Mazurek, and Haenlein, 2019).

Using the Rekruter Lite tool, which allows to analyze selected profiles and their contents in the form of a compact list, a research sample including profiles of general managers of hotels and HR managers in hotels declaring internship in a given position not shorter than three years was created. In this way, a group of 361 managers was identified with whom an attempt to contact via the portal of LinkedIn was made. A questionnaire was presented to those who volunteered to participate in the study (52). All managers who had been interviewed over the phone and in person via the LinkedIn portal beforehand declared their participation in the study, providing their telephone numbers and being invited to the meeting during which they would answer the questions of questionnaire; 52 managers represented 57 hotels, which resulted from the fact that two of them manage simultaneously two objects and one is an HR manager in a network of three hotels. In total, 52 opinions of hotel directors $(42 \%)$, deputy directors $(21.2 \%)$, HR managers $(7.7 \%)$, HR specialists $(9.6 \%)$ and other specialists $(17.3 \%)$, who were considered competent in the examined area about completing the questionnaire, were collected. Most managers represented 3-star $(44.2 \%)$ and 4 -star $(36.5 \%)$ hotels, the smaller group were represented by 5 -star (9.6\%), 2-star (7.7\%) and 1-star (1. 9\%) hotels. It is worth noting that $50 \%$ of respondents are managers of the analyzed independent hotels, $14(26.9 \%)$ represented hotels belonging to foreign hotels and $12(23.1 \%)$ - to Polish hotel chains.

In the course of research on the relationships between motivators used by managers and hotel features, i.e. size (number of full-time employees), category (number of stars) and networking (belonging to hotel chains), Spearman's rank correlation coefficient was used. All calculations were carried out using the STATISTICA 12 package.

\section{Research results}

Analysis of the results of the conducted research showed (Table 1) that all managers participating in the study provide their employees with a positive atmosphere at work. The vast majority also try to take care of good relations with their employees, show them respect and credit, reward their employees for good performance at work, and provide high wages and flexible working hours. In just two cases the managers indicated that they had never used two of the aforementioned motivators, 
i.e. increased responsibility for work and its effects and flexible working time. The remaining group of managers indicated that they use these motivators frequently and very frequently.

Less frequently used incentives to encourage hotel employees to remain in the enterprise and show greater involvement in their work are privileges (e.g. discounts in hotels and/or restaurants for the employees and their family members), benefit packages (e.g. health or social ones), promotion and development opportunities, including internal mobility as well as social facilities that meet the highest standards. In the case of the last of these motivators, as many as $25 \%$ of managers underestimate its role in building employee satisfaction and commitment. The results are similar in terms of offering employees health programs (e.g. wellness, rehabilitation, addiction therapy) and well-being (taking care of the well-being of the employees). As few as $25 \%$ of managers use them frequently or very frequently. Nearly $30 \%$ of managers do not provide their employees with access to technology and work supporting tools at all or they do it rarely.

Definitely the least frequently used motivators are those based on modern technologies and communication techniques, i.e. platforms for sharing ideas and systems enabling multidirectional communication. Half of the respondents indicated that they had never used such motivators. It is also rare to provide employees with mobile learning management systems, the use of a personalized, holistic and flexible remuneration system, and employee participation in management.

The conducted research also allowed to indicate statistically significant positive correlations between 12 motivators from the 19 (indicated in Table 1) and selected hotel features, i.e. size, category and network (Table 2).

The results of the conducted research show that a statistically significant high positive correlation $(R=0.480 ; p<0.000)$ exists between the size of the company and the high rating of the importance of promotion and development opportunities in the hotel. The research also confirmed a statistically significant positive correlation between the size of the hotel and the rewarding of employees for achieving good results at work $(R=402 ; p<0.003)$, providing the possibility of employee transfer between departments, processes, divisions and branches $(\mathrm{R}=0.355 ; p<0.010)$, providing access to technologies and tools supporting the work of employees $(R=0.290 ; p<0.037)$, a talent development support system $(R=298 ; p<0.032)$, employee participation in hotel management $(R=0.312 ; p<0.024)$ and access to mobile learning management systems $(R=0.318 ; p<0.022)$. This indicates that as the size of hotels increases, these motivators are more often used by managers.

The results of dependency analysis are slightly different if the standard of the hotel represented by respondents/managers is taken into account. In this case, a statistically significant high positive correlation was confirmed in relation to the motivator of offering social facilities to employees $(R=0.473 ; p<0.000)$. Slightly weaker relationships are also found between the hotel category and the use of a personalized, holistic and flexible remuneration system $(R=0.367 ; p<0.007)$, 
Table 1. Most common motivators

\begin{tabular}{|c|c|c|c|c|c|}
\hline Motivators & Never & Seldom & Sometimes & Frequently & $\begin{array}{l}\text { Very } \\
\text { frequently }\end{array}$ \\
\hline Provision of a positive work atmosphere & 0 & 0 & 0 & 18 & 34 \\
\hline Taking care of employee-supervisor relations & 0 & 0 & 1 & 21 & 30 \\
\hline Showing credit and respect to employees & 0 & 1 & 2 & 19 & 30 \\
\hline Increasing responsibility for work and its effects & 1 & 0 & 18 & 11 & 22 \\
\hline Rewarding employees for good work results & 0 & 3 & 15 & 14 & 20 \\
\hline Flexible working hours & 1 & 6 & 6 & 20 & 19 \\
\hline Privileges and benefit packages & 1 & 7 & 18 & 12 & 14 \\
\hline Provision of internal mobility & 3 & 11 & 16 & 12 & 10 \\
\hline High salary & 1 & 3 & 11 & 30 & 7 \\
\hline Health and well-being programs & 15 & 10 & 13 & 8 & 6 \\
\hline Promotion and development opportunities & 7 & 13 & 15 & 12 & 5 \\
\hline Provision of social facilities & 13 & 14 & 12 & 8 & 5 \\
\hline $\begin{array}{l}\text { Provision of access to technologies and tools } \\
\text { supporting the work of employees }\end{array}$ & 3 & 13 & 15 & 17 & 4 \\
\hline $\begin{array}{l}\text { Provision of a talent development support } \\
\text { system }\end{array}$ & 21 & 5 & 16 & 7 & 3 \\
\hline Access to mobile learning management systems & 15 & 13 & 17 & 4 & 3 \\
\hline Employee participation in management & 5 & 14 & 24 & 7 & 2 \\
\hline $\begin{array}{l}\text { Systems enabling multidirectional } \\
\text { communication between employees }\end{array}$ & 24 & 6 & 13 & 8 & 1 \\
\hline $\begin{array}{l}\text { Personalized, holistic and flexible remuneration } \\
\text { system }\end{array}$ & 12 & 19 & 16 & 4 & 1 \\
\hline Access to platforms for sharing ideas & 27 & 12 & 10 & 3 & 0 \\
\hline
\end{tabular}

Source: based on own research.

providing employees with access to systems enabling multidirectional communication $(R=0.353 ; p<0.010)$. Similarly to the size of the hotel, its standard appears to have an impact on the more frequent motivators used by managers such as providing employees with access to technologies supporting employees' work, which is confirmed by the correlation index $(R=0.339 ; p<0.014)$.

The conducted research also shows that there is a statistically significant high positive correlation between hotels belonging to hotel chains and a high assessment of the importance of promotion and development opportunities in a hotel, talent development support system, access to mobile learning management systems and platforms for sharing ideas $(R=0.728 ; p<0.000, R=0.659 ; p<0.000, R=0.529$; $p<0.000, \mathrm{R}=0.561 ; \mathrm{p}<0.000)$. As it can be seen in relation to the first three of these motivators, there is a visible dependence on both the size and belonging to the hotel chain, however the dependence for the second feature is definitely stronger. Managers representing network hotels also more often use motivators such as privileges and 
Table 2. Values of Spearman rank correlation coefficients and results of the test of their significance for selected hotel features

\begin{tabular}{|l|c|c|c|c|c|c|}
\hline \multirow{2}{*}{ Hotel features } & \multicolumn{2}{|c|}{ Size } & \multicolumn{2}{c|}{ Category } & \multicolumn{2}{c|}{ Network } \\
\cline { 2 - 7 } & $R$ & $p$ & $R$ & $p$ & $R$ & $p$ \\
\hline Credit and rewarding & $\mathbf{0 . 4 0 2}$ & $\mathbf{0 . 0 0 3}$ & 0.269 & 0.054 & 0.224 & 0.110 \\
\hline Privileges and benefit packages & 0.129 & 0.360 & 0.122 & 0.388 & $\mathbf{0 . 4 4 5}$ & $\mathbf{0 . 0 0 1}$ \\
\hline Provision of internal mobility & $\mathbf{0 . 3 5 5}$ & $\mathbf{0 . 0 1 0}$ & 0.169 & 0.232 & 0.260 & 0.063 \\
\hline Health and well-being programs & 0.014 & 0.924 & 0.150 & 0.289 & $\mathbf{0 . 4 2 6}$ & $\mathbf{0 . 0 0 2}$ \\
\hline Promotion and development opportunities & $\mathbf{0 . 4 8 0}$ & $\mathbf{0 . 0 0 0}$ & 0.227 & 0.106 & $\mathbf{0 . 7 2 8}$ & $\mathbf{0 . 0 0 0}$ \\
\hline Social facilities & 0.206 & 0.143 & $\mathbf{0 . 4 7 3}$ & $\mathbf{0 . 0 0 0}$ & 0.008 & 0.954 \\
\hline Access to employee work supporting technologies & $\mathbf{0 . 2 9 0}$ & $\mathbf{0 . 0 3 7}$ & $\mathbf{0 . 3 3 9}$ & $\mathbf{0 . 0 1 4}$ & $\mathbf{0 . 4 4 5}$ & $\mathbf{0 . 0 0 1}$ \\
\hline Talent development support system & $\mathbf{0 . 2 9 8}$ & $\mathbf{0 . 0 3 2}$ & 0.236 & 0.092 & $\mathbf{0 . 6 5 9}$ & $\mathbf{0 . 0 0 0}$ \\
\hline Access to mobile learning management systems & $\mathbf{0 . 3 1 8}$ & $\mathbf{0 . 0 2 2}$ & 0.198 & 0.159 & $\mathbf{0 . 5 2 9}$ & $\mathbf{0 . 0 0 0}$ \\
\hline Employee participation in management & $\mathbf{0 . 3 1 2}$ & $\mathbf{0 . 0 2 4}$ & 0.152 & 0.281 & 0.145 & 0.304 \\
\hline $\begin{array}{l}\text { Access to systems enabling multidirectional } \\
\text { communication }\end{array}$ & 0.150 & 0.288 & $\mathbf{0 . 3 5 3}$ & $\mathbf{0 . 0 1 0}$ & $\mathbf{0 . 4 1 9}$ & $\mathbf{0 . 0 0 2}$ \\
\hline $\begin{array}{l}\text { Personalized, holistic and flexible remuneration } \\
\text { system }\end{array}$ & 0.254 & 0.069 & $\mathbf{0 . 3 6 7}$ & $\mathbf{0 . 0 0 7}$ & 0.092 & 0.515 \\
\hline Access to platforms for sharing ideas & 0.199 & 0.157 & 0.135 & 0.340 & $\mathbf{0 . 5 6 1}$ & $\mathbf{0 . 0 0 0}$ \\
\hline
\end{tabular}

Source: based on own research.

benefit packages $(R=0.445 ; p<0.001)$, providing access to technologies supporting employees' work $(\mathrm{R}=0.445 ; p<0.001)$, systems enabling multidirectional communication $(R=0.419 ; p<0.002)$ and access to health and well-being programmes $(R=0.426 ; p<0.002)$. At the same time, not only does the belonging to the hotel chain, but also the size of the hotel affect the more frequent use of the motivator of providing access to systems enabling multidirectional communication and providing access to technologies supporting employees' work. With regard to the latter motivator, it is clearly visible that there is a statistically significant correlation between the motivator and all analyzed hotel features, i.e. size, category and belonging to the hotel chain.

\section{Discussion}

The results of the research showed that managers are increasingly using the so-called soft approach to human capital management in which employees are treated subjectively rather than objectively as in the hard approach. Therefore, first and foremost, it is important to provide a positive work atmosphere that encourages employees to stay in the company for longer. A positive work atmosphere, care for relationships with colleagues and showing respect and giving credit to employees are an important factor in building an organizational culture conducive to increasing 
job satisfaction. Hotels employ people of different backgrounds, cultures and ages, so it is important to create a culture in which employees work effectively as a team and respect each other. In this way, trust is built in the organization, which provides the basis for increasing responsibility for work and its effects, which provides the basis for increasing responsibility for work and its effects. And this, as proven by numerous studies (Karatepe and Uluda, 2007; Lee-Ross, 2005; Wasike and Ndivo, 2015), is a factor strongly affecting employee involvement and motivation.

Hotel managers, as shown in the presented research results, see the potential of employees in building the success of an organization by using non-financial motivators. It proves that the role of financial motivators is not dominant. However, this must not be forgotten in the context of problems related to hotel payroll policies and reported by employees, i.e. unclear and unfair remuneration systems (cf. Pizam 2015; DiPietro and Condly, 2007), late payment of salary, no overtime payment (Tokarz-Kocik, 2018). This is even more important as the research carried out by Smith $(2015$, p. 28) shows that among employees who do not understand the rules of remuneration, the probability of changing employers is $60 \%$ higher. In turn, Globoforce (2018) proves that employees who regularly receive smaller awards, e.g. cash, show up to eight times more commitment than those who can expect a pay increase or bonus once a year. Flexible payroll programs are also becoming more and more popular, as they provide more frequent than only once a year increases, bonuses or other incentives. It is conditioned by employees' growing expectations regarding the transparency of the rules, as well as the flexibility of the remuneration system, as well as better access to information, e.g. on the amount of remuneration that can be found on the websites of portals integrating employees of various industries. As the research results presented in the article show, managers of Polish hotels rarely use personalized, holistic and flexible remuneration systems. At the same time, the frequency of using this motivator increases with the standard of the hotel. Remuneration programmes characterized by greater liquidity, more tailored to individual preferences and more dependent on the employee's overall commitment to both the team and the entire enterprise, can determine the competitive advantage of a hotel.

The hotel industry is dominated by young employees (Eurostat, 2017), therefore, while building effective incentive systems, hoteliers should not forget about the needs of the young and digital generation that is strongly attached to modern technologies and completely unattached to one workplace. Therefore, in order to not only attract younger candidates who are familiar with digital technology, but also to meet their expectations regarding cooperation, access to information and mobile learning, both cultural and technological transformation in motivating hotel employees will be required. As the research shows, on average, young employees simultaneously use three devices (smartphone, laptop, tablet, etc.) (Romer, 2014, p. 13, after: Sarzyński). Emerging technological and digital solutions are intended to help employees perform their work better and more effectively. The development 
of digital communication tools also changes the way of interaction between employees, who more and more often use collaboration platforms (i.e. slack, Basecamp, trello) or social media related to the work environment (e.g. LinkedIn) or instant messaging (e.g. Messenger, Skype) for this purpose. Therefore, investments in technologies and digital tools supporting the effectiveness of incentive programms should be permanently included in the budget plans of hotel enterprises. Unfortunately, as the results of research conducted among 52 managers show, motivators using the benefits of IT technology and digital solutions are the least used in hotels. The correlation analysis showed that large and luxury hotels belonging to global hotel chains use this type of motivators slightly more often. This is probably due to the need to use digital solutions imposed by large corporations that are able to predict changes in employees' behaviour and their attitude to the workplace and its equipment.

The systematic increase of employees' access to modern digital solutions may contribute to levelling the problems faced by hotels, related to overwork, limited development opportunities and a low level of innovation. Providing employees with access to mobile learning management systems will allow them to select courses and trainings appropriate for their needs and develop more freely (including a convenient place and time) both in the current workplace and in other directions of their choice. In addition, it will significantly reduce investment costs in traditional forms of employee training, which often turn out to be mismatched to the needs and capabilities of the employee. Access to technologies and tools supporting the work of employees will make employees feel less overworked, stressed and frustrated by performing some routine manual processes. In this way, hotels will provide a balance between work and personal life which is so important for modern employees, and thus will affect their well-being. The use of motivators providing access to technologies facilitating the work of employees as well as health and well-being programms can successfully increase the employee's well-being and their willingness to be more involved in the work for the hotel.

The rare use of motivators focused on providing employees with the availability of systems enabling multidirectional communication between them as well as platforms for sharing ideas shows that Polish managers underestimate the importance of communication, the lack of which results in low performance, poor service and increased costs, which was proved by Kovach in 1987. Fast, trouble-free flow of information between the hotel and the guest is the basis for building a competitive advantage on the modern market. However, it is difficult to provide it when it is not functional enough inside the hotel. Hence, providing employees with systems enabling multidirectional communication should become a standard in hotels. Lack of access to such solutions may have a demotivating effect on employees. Good communication is one of the basic factors that motivate employees to work more effectively and to be more involved. 


\section{Conclusion}

Keeping up with market trends in motivating employees is a must in leadership roles. The speed of changes taking place in the environment of the organization, including the development of modern technologies, generational and cultural diversity, mean that the lack of adjustment of incentive systems to the needs and requirements of employees may result in their loss. The results of the presented research allowed to indicate the most common ways of motivating line employees used by hotel managers in Poland, i.e. care for providing a good atmosphere at work, relations between the employee and supervisor, and showing respect and giving credit to them. This indicates that the role of line employees in hotels is appreciated. On the other hand, the research proves that hotel managers in Poland do not fully use modern trends in motivating employees, including agile, holistic and flexible remuneration systems, as well as providing access to technologies and supporting tools that improve employees' work, their development and communication within the hotel. Only a few managers, usually representing large, high standard hotels that belong to global chains, indicated the use of these ways to motivate employees.

This is even more important in the face of the increasingly common automation process and the development of artificial intelligence. Managers should provide employees with access to efficient and effective work and professional development tools, as well as personalize the remuneration system. Lack of access to such solutions not only reduces the effectiveness of employees' work, but also the perception of the employer as a person who does not respect their employees. It reduces motivation to work and increases the risk of an employee leaving the job.

Despite the management implications, the presented study has several limitations. The results are based on a relatively small research sample, whose structure is slightly different from the structure of hotels in Poland. It is therefore worth expanding the research to a larger group of hotels so that one can generalize the research results. The measurement of the motivation methods was also limited to 19 . And even though these methods were included in other studies and their weight was tested, there may be other relevant motivators. In addition, the indicated correlations concerned only three features of hotels, which does not fully exploit the subject and requires an extension of research in this direction.

\section{Bibliography}

Çetin, I. (2013). Motivation and its impact on labour productivity at Hotel business "a conceptual study". International Journal of New Trends in Arts, Sports \& Science Education, 2(1), 70-79.

Cheng, A., and Brown, A. (1998). HRM strategies and labour turnover in the hotel industry: A comparative study of Australia and Singapore. International Journal of Human Resource Management, 9(1), 136-154. 
Consultants of Hospitality Administrators International. (2012). The employee turnover - the challenge. Retrieved 12 September 2019 from http://www.cha-international.com/The-Hotel-Employer-Turnover

Deery, M. A., and Shaw, R. N. (1999). An investigation of the relationship between employee turnover and organizational culture. Journal of Hospitality \& Tourism Research, 23(4), 387-400.

Deloitte. (2017). Rewriting the rules for the digital age (Deloitte global human capital trends report). Deloitte University Press.

Deloitte. (2019). Leading the social enterprise. Reinvent with a human focus (Deloitte global human capital trends report). Deloitte University Press.

DiPietro, R. B., and Condly, S. J. (2007). Employee turnover in the hospitality industry: An analysis based on the CANE model of motivation. Journal of Human Resources in Hospitality \& Tourism, $6(1), 1-22$.

Enz, C. A. (2001). What keeps you up at night? Key issues of concern for lodging managers. Cornell Hotel and Restaurant Administration Quarterly, 42(2), 38-45.

Eurostat. (2017). Tourism industries - employment in 2016. Retrieved from: https://ec.europa.eu/eurostat/statistics-explained/index.php/Tourism_industries_-_employment\#The_tourism_industries_employ_over_13_million_people_in_the_EU

Gordon, S., and Adler, H. (2017). Employee perceptions of well-being and organizational wellness offerings: A study of line-level employees in select-service hotels. Journal of Human Resources in Hospitality \& Tourism, 16(3), 308-330.

Karatepe, O. M. (2009). The effects of involvement and social support on frontline employee outcomes: Evidence from the Albanian hotel industry. International Journal of Hospitality \& Tourism Administration, 10(4), 326-343.

Karatepe, O. M., Beirami, E., Bouzari, M., and Safavi, H. P. (2014). Does work engagement mediate the effects of challenge stressors on job outcomes? Evidence from the hotel industry. International Journal of Hospitality Management, 36, 14-22.

Karatepe, O. M., and Uludag, O. (2007). Conflict, exhaustion, and motivation: A study of frontline employees in Northern Cyprus hotels. International Journal of Hospitality Management, 26(3), 645-665.

Kingir, S., and Mesci, M. (2010). Factors that affect hotel employees motivation, the case of Bodrum. Serbian Journal of Management, 5(1), 59-76.

Korzynski, P., Mazurek, G., and Haenlein, M. (2019). Leveraging employees as spokespeople in your HR strategy: How company-related employee posts on social media can help firms to attract new talent. European Management Journal.

Kovach, K. A. (1987). What motivates employees? Workers and supervisors give different answers. Business Horizons, 30(5), 58-65.

Lee-Ross, D. (2005). Perceived job characteristics and internal work motivation: An exploratory cross-cultural analysis of the motivational antecedents of hotel workers in Mauritius and Australia. Journal of Management Development, 24(3), 253-266.

Leisink, P., and Steijn, B. (2009). Public service motivation and job performance of public sector employees in the Netherlands. International Review of Administrative Sciences, 75(1), 35-52.

Maroudas, L., Kyriakidou, O., and Vacharis, A. (2008). Employees' motivation in the luxury hotel industry: The perceived effectiveness of human-resource practices. Managing Leisure, 13(3-4), 258-271.

Mhlanga, O. (2018). Customer experiences and return patronage in airport hotels: Evidence from OR Tambo International Airport, South Africa. Acta Commercii, 18(1), 1-11.

Pandey, S. K., Wright, B. E., and Moynihan, D. P. (2008). Public service motivation and interpersonal citizenship behavior in public organizations: Testing a preliminary model. International Public Management Journal, 11(1), 89-108. 
Pizam, A. (2015). Salaries and wages in the US lodging industry: Are they as low as the general perception? International Journal of Hospitality Management, 51, 157-158.

Polski LinkedIn w liczbach. (2019). Retrieved from https://sharebee.pl/blog/polski-linkedin-wliczbach-2019.)

Ritz, A. (2009). Public service motivation and organizational performance in Swiss federal government. International review of administrative sciences, 75(1), 53-78.

Romer, H. (2014). Best practices for BYOD security. Computer Fraud \& Security, (1), 13-15.

Rowley, G., and Purcell, K. (2001). 'As cooks go, she went': Is labour churn inevitable? International Journal of Hospitality Management, 20(2), 163-185.

Sarzyński, K. (2016). Bring Your Own Device (BYOD) - szansa czy zagrożenie dla przedsiębiorstwa? Organizacja i Zarzqdzanie: Kwartalnik Naukowy.

Smith, D. (2015). Most people have no idea whether they're paid fairly. Harvard Business Review, (12).

Society for Human Resource Management and Global Force. (2018). SHRM/Globoforce employee recognition report, 2018.

Szafrański, A., and Piasta, J. (2019). Stres w pracy hotelarza. Retrieved 9 September 2019 from http:// www.e-hotelarstwo.com/tematy/raport?more $=1847466946$

Tang, T. L. P., and Chiu, R. K. (2003). Income, money ethic, pay satisfaction, commitment, and unethical behavior: is the love of money the root of evil for Hong Kong employees? Journal of Business Ethics, 46(1), 13-30.

Taylor, B. M. (2015). The integrated dynamics of motivation and performance in the workplace. Performance Improvement, 54(5), 28-37.

Tokarz-Kocik, A. (2018). Motivation as a source of human resource risk in hospitality enterprises. Theoretical approach. Journal of Economic and Social Development, 5(2), 44-53.

Wasike, M. C. K., and Ndivo, R. M. (2015). Efficacy of motivation strategies in addressing employee motivation needs in Kenya's hotel sector. African Journal of Hospitality, Tourism and Leisure, 4(1), 1-10.

Wszendybył-Skulska, E. (2013). Motivácia a odmeňovanie zamestnancov v hotelierstve. Ekonomická Revue Cestovného Ruchu, 46(2).

Wziątek-Staśko, A. (2016). The extent of managers' motivation as a determinant of leadership quality. Ekonomia i Zarzqdzanie, 8(1), 37-46.

Yeboah, M. A., and Abdulai, A. (2016). Evidence of Herzberg's motivation - hygiene theory in small and medium enterprises through the lens of a three-star hotel. International Journal of Research -GRANTHAALAYAH, 4(11), 23-36. 